\title{
Verosuunnittelukeinot kehittyvällä maatilalla - Case Peltolan tila
}

\author{
Henni Sirviö ${ }^{2}$; Mikko Toivanen ${ }^{2}$; Hannu Viitala ${ }^{1}$; Pirjo Suhonen ${ }^{1}$ \\ 1) Savonia-ammattikorkeakoulu,PL 72, 74101 Iisalmi, etunimi.sukunimi@ savonia.fi \\ 2) Savonia-annattikorkeakoulu, PL 72, 74101 Iisalmi, toivalantila@gmail.fi
}

\section{Tiivistelmä}

Verosuunnittelulla pyritään maataloudessa optimoimaan maatilan verotusta ja taloutta lain puitteissa, pitkällä aikavälillä. Usein verosuunnittelu koetaan kuitenkin hankalaksi ja pitkän aikavälin suunnittelun sijaan pyritään minimoimaan verot lyhyellä aikavälillä. Lyhyellä aikajänteellä saavutettu verohyöty voi kostautua myöhemmin lisääntyneinä veroina.

Tässä työssä tutkittiin verosuunnittelukeinoja kehittyvällä maatilalla. Toiminta jaettiin pitkän aikavälin suunnitteluun, verovuonna tehtävään suunnitteluun sekä tilinpäätöksen yhteydessä tehtävään verosuunnitteluun. Verosuunnittelua käydään läpi erityisesti investointien, sukupolvenvaihdoksen sekä toimintamuodon muutoksen yhteydessä. Maatilan verosuunnittelun kannalta on tärkeää saada tilan tuloksentekokyky kuntoon, nettovarallisuus hyvälle tasolle ja sukupolvenvaihdokseen sekä investointeihin on syytä varautua huolellisesti. Suunnitelmapoistot ja rahoitusratkaisut ovat myös tärkeässä roolissa verosuunnittelun kannalta.

Verosuunnittelua kehittyvällä maatilalla kuvataan kuvitteellisen Case Peltolan maatilan avulla. Tilalle pyrittiin luomaan mahdollisimman monta elementtiä, joissa verosuunnittelua kannattaa hyödyntää. Tilalla tehtiin vaiheittainen sukupolvenvaihdos kahdessa vaiheessa, investoitiin tuotantoon ja tila myös osakeyhtiöitti toimintansa. Työssä käytiin läpi näitä vaiheita ja eroja, joita perheviljelmän, maatalousyhtymän ja osakeyhtiön välillä verosuunnittelussa on. Erilaisia verosuunnittelukeinoja havainnollistettiin kuvioiden ja taulukoiden avulla.

Tiedot on koottu asiantuntijahaastatteluiden, alan kirjallisuuden sekä tekijöiden omien kokemusten pohjalta. Verosuunnittelu on liian vähän hyödynnetty aihealue maatilan talouden ylläpidossa. Työ pyrkii madaltamaan kynnystä verosuunnitteluun ja tuomaan tietoa viljelijätasolle, mutta myös asiantuntijoille sekä hallinnolle.

Vaiheittaisella sukupolvenvaihdoksella saavutettiin merkittävää verosuunnittelullista etua Peltolan tilalla. Jaettaessa tulos aiemman kahden henkilön sijaan kolmelle, oli ansiotuloveroaste huomattavasti pienempi ja myös pääomatuloverotuksen osalta vältettiin progressiota. Samalla nuori yrittäjä saatiin sitoutumaan maatilan toimintaan ja hänen oli mahdollista tehdä muun muassa lisämaan hankintoja omiin nimiinsä. Yhtiöitettäessä Peltolan tilan toiminta, maatila kykeni hankkimaan lisäpeltoa verosuunnittelun kannalta edullisemmin. Peltolan tilan yksityistalouden menojen ollessa maltilliset, pystyi yrittäjäpariskunta jättämään osan tilan tuloksesta yhtiöön esimerkiksi korvausinvestointeja silmällä pitäen.

Tuloksentekokyvyn laittaminen maatilalla kuntoon on ensiarvoisen tärkeää tilan menestymisen kannalta. Nettovarallisuus on pyrittävä saamaan mahdollisimman hyvälle tasolle. Suunnitelmalliset poistot ja verovelan syntymisen välttäminen ovat keskeisessä roolissa onnistunutta verosuunnittelua pohdittaessa. Poistokohteet tulee järjestää oikeaan järjestykseen, jotta nettovarallisuuden säilyttäminen hyvällä tasolla sekä maksettavan kiinteistöveron määrä olisi huomioitu tilan verosuunnittelussa. Poistojen määrä kannattaa suhteuttaa lainan lyhennysten määrään.

Asiasanat: Verosuunnittelu, verotus, sukupolvenvaihdos, osakeyhtiöt 


\section{Johdanto}

Verotus koetaan monilla suomalaisilla maatiloilla monimutkaiseksi ja hankalaksi, eikä siihen aina paneuduta riittävän hyvin. Tiedon ja mielenkiinnon puute sekä asiantuntijapalveluiden käyttämättömyys johtavat usein lyhytnäköiseen verosuunnitteluun, jossa päämääränä on minimoida veroseuraamukset kyseisenä verovuonna. Veroseuraamusten minimointi onnistuu varsin helposti lyhyellä aikajänteellä, mutta sen haitat alkavat näkyä jo muutaman vuoden kuluessa, kun veroseuraamukset kasvavat, minimointikeinojen huvetessa. (Savolainen 2015.)

Verosuunnittelulla maataloudessa tarkoitetaan toimia, joilla verotusta pyritään keventämään lain rajaamissa puitteissa. Verosuunnittelua voidaan toteuttaa pitkän aikavälin suunnittelulla, verovuoden aikaisilla ratkaisuilla sekä tilinpäätöksen yhteydessä tehtävillä toimenpiteillä. Sillä pystytään saavuttamaan merkittävää kilpailuetua maatalouden rintamalla. Tuotannoltaan ja ulkoisesti hyvin samankaltainen maatila voi huonolla suunnittelulla kuluttaa merkittävästi enemmän rahaa verojen maksuun. Saavutettu verohyöty mahdollistaa säästetyn rahan käyttämisen maatilan kehittämiseen. Ei ole verottajankaan etu, että maatilalla menee taloudellisesti huonosti, jos käyttöpääoma kuluu verojen maksuun. Hyvin menestyvä ja verosuunnittelua harjoittava maatila maksaa veronsa, pystyen samalla tekemään hyvää tulosta ja mahdollisesti työllistämään maatalousyrittäjien lisäksi muita verovelvollisia. (Agronet 2014.)

Työssä pyrittiin avaamaan niitä keinoja, joita kehittyvän maatilan kannattaa ottaa huomioon verosuunnittelussaan. Työ on kehittämistyö, jossa case-sovelluksen avulla havainnollistettiin kehittyvän maatilan verosuunnitteluun, etenkin tuloverotukseen, liittyviä asioita. Case-maatilalla suoritettiin vaiheittainen sukupolvenvaihdos ja juuri tätä ennen oli investoitu tuotantoon. Maatila pyrki kehittymään koko ajan ja työssä käytiin läpi myös sukupolvenvaihdoksen toinen vaihe verosuunnittelua painottaen. Lopulta toiminnan laajentuessa jatkajat päättivät osakeyhtiöittää tilan toiminnan. Verosuunnittelukohteista keskityttiin kolmeen eri osa-alueeseen; investoinnit, sukupolvenvaihdos sekä maatilan yhtiöittäminen. Luotu case-maatila oli tuloksentekokyvyltään erittäin hyvä, koska hyvin tuottavalla maatilalla on enemmän mahdollisuuksia harjoittaa verosuunnittelua ja näin ollen näitä keinoja oli helpompi havainnollistaa. Työ toteutettiin syksyn 2014 ja kevään 2015 aikana Savonia-ammattikorkeakoulun toimeksiantamana agrologitutkinnon opinnäytetyönä.

\section{Aineisto ja menetelmät}

Kehittämistyön tavoitteena oli ohjeistaa sekä järkeistää ammatillista käytännön toimintaa. Aiheen tarkastelun helpottamiseksi luotiin kuvitteellinen case-maatila, joka on nykyaikainen, kehittyvä ja hyvää tulosta tekevä maatalousalan yritys. Case-tila halusi ottaa toiminnassaan myös verosuunnittelun huomioon. Case-tutkimus eli tapaustutkimus toimii työssä käytännössä tutkimuksellisena näkökulmana. Sen avulla pystyttiin analysoimaan monipuolista ja eri tavoin hankittua tietoa rajatusti. Selittävän case-tutkimuksen avulla oli mahdollista luoda kokonaisvaltainen ja seikkaperäinen kuvaus, kun käsiteltiin hyvin monisyistä aihetta. Tässä työssä casemaatila nimettiin Peltolan maatilaksi. Tila on melko laaja, mutta realistinen esimerkki pohjoissavolaisesta maatilasta. Case-maatilalla pyrittiin havainnollistamaan verosuunnittelun merkitystä erilaisten laskelmien ja esimerkkien avulla.

Tiedonkeruumenetelmänä käytettiin asiantuntijahaastatteluja. Haastateltavina asiantuntijoina toimivat verotuksen ja taloushallinnon asiantuntija Risto Savolainen, ProAgria Pohjois-Savosta yritysasiantuntija Juhani Paavilainen sekä omistusjärjestelyiden erityisasiantuntija Kyösti Laajalahti. Case-sovelluksessa verojenlaskennassa on hyödynnetty Verohallinnon veroprosenttilaskuria, ProAgria Länsi-Suomessa talousasiantuntijana toimineen Esko Aallon kehittämää taulukkolaskentapohjaista Vero-Esko 2014 -laskuria sekä Savoniaammattikorkeakoulun Maatilan verosuunnittelu -opintojaksolla hyödynnettävää taulukkolaskentapohjaista verolaskuria.

\section{Tulokset ja tulosten tarkastelu}

\section{Maatalouden verotus on riippuvainen tulolähteestä}

Suomessa on käytössä tulolähdejako, joka sisältää kolme eri tulolähdettä: maatalouden, elinkeino-toiminnan ja muun toiminnan tulolähde (Kuvio 1.). Tulolähde määritellään tulonhankkimistavan mukaan ja tulolähteestä riippuen valitaan laki, jonka mukaan verotettava tulo määritellään. (Verohallinto 2011.) Maataloutta harjoittavalla verovelvollisella voi olla jopa kolme eri tulolähdettä. Yritysmuoto ei vaikuta tulolähdejakoon, vaan se 
määritellään tulonhankkimistoiminnan luonteen mukaan.

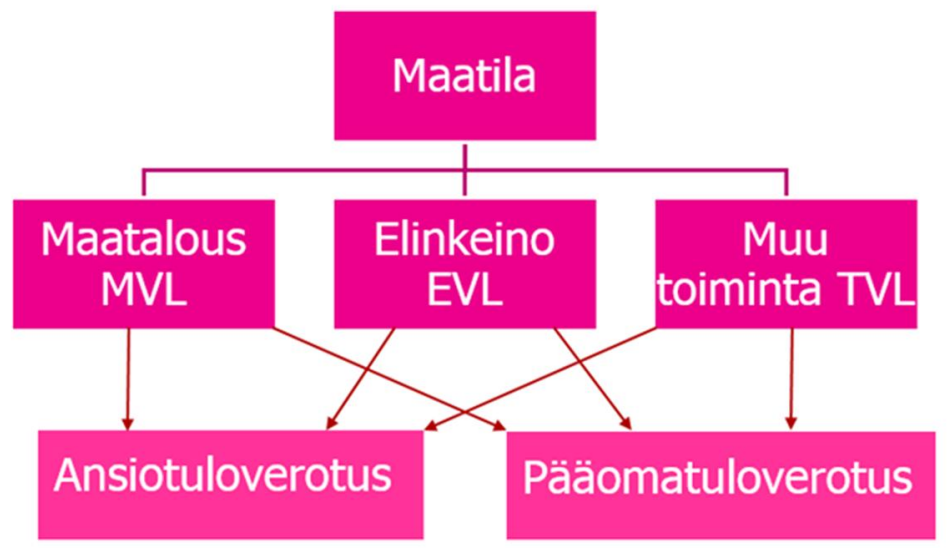

KUVIO 1. Maatilan tulolähteet (Kiviranta 2013, 39; Verohallinto 2011.)

Perinteisesti maatalouden harjoittaminen on maatilatalouden tuloverolain (MVL) alaista toimintaa eli verotettava tulo määritetään kyseenomaisen lain mukaisesti. Toiminnasta jätetään maatilan veroilmoitus, 2-lomake. Jos maatilalla harjoitetaan esimerkiksi laajamittaista urakointia, Verohallinto voi katsoa toiminnan elinkeinotoiminnaksi ja verottaa sitä elinkeinoverolain (ELV 360/1968) mukaisesti. Muun toiminnan tulolähteitä verotetaan tuloverolain (TVL) mukaan, esimerkiksi metsätaloutta verotetaan henkilöverotuksessa tuloverolain mukaisesti. Jokainen metsänomistaja jättää vuosittain erillisen metsäveroilmoituksen, lomakkeella 2C. Kutakin tulonlähdettä verotetaan ansio- ja pääomatuloverotuksen piirissä veroilmoituksesta riippuen. (Finlex, 2014.; Kiviranta 2013, 39.; Koivumäki 2011; Ojala 2005.)

\section{Verosuunnittelu tilikauden aikana}

Verovuoden aikana tapahtuvat kaikki verotuksessa huomioitavat tulo- ja menotapahtumat. Tulojen ja menojen ajoituksella voi olla verotuksen kannalta keskeinen merkitys. Suuret tulo- ja menoerät kannattaa suunnitella verovuosittain tasaisesti, jotta suurilta tulo- tai menopiikeiltä vältytään. (Aalto 2013.)

Yksi hyödynnettävistä verosuunnittelukeinoista on maksaa 15-17-vuotiaalle lapselle palkkaa maatilalla tehdystä työstä (Taulukko 1.). Maksettaessa lapselle palkkaa pienenee yrittäjien verotettava tulo, mutta raha pysyy perheen sisällä. Samanaikaisesti pääomatulo-osuuden laskentaperusteena olevaa nettovarallisuutta kerrytetään

$30 \%: 1 l a$ maksetuista ennakonpidätyksen alaisista palkoista. Palkanmaksu tuo verovähennyksiä sekä parantaa pääomatulo-osuuden optimointimahdollisuuksia. (Savolainen 2015, 42-43.)

TAULUKKO 1. Maksamalla 15-17-vuotiaalle lapselle palkkaa tehdystä työstä saadaan huomattavia verosäästöjä. (Savolainen $2015,42 \neg 43$.)

\begin{tabular}{|c|c|c|c|}
\hline $\begin{array}{c}\text { 15-17-vuotiaalle } \\
\text { maksettava palkka, } \\
€\end{array}$ & $\begin{array}{c}15-17-\text { vuotiaan } \\
\text { verot, } €\end{array}$ & $\begin{array}{c}\text { Vanhemmalle koituva vero, } \\
\text { mikäli palkkaa ei makseta, } \\
\text { vero-\% } 40 \%, €\end{array}$ & Verosäästö, $€$ \\
\hline 8000 & 80 & 3200 & 3120 \\
\hline 10000 & 320 & 4000 & 3680 \\
\hline 12000 & 600 & 4800 & 4200 \\
\hline 14000 & 1000 & 5600 & 4600 \\
\hline
\end{tabular}

\section{Verosuunnittelu tilinpäätöksen yhteydessä}

Tilinpäätöksen yhteydessä laaditaan maatilan verokirjanpito, jonka pohjalta voidaan laatia maatilan veroilmoitus. Tilinpäätöshetkellä tehdään suunnitelman mukaiset poistot sekä mahdolliset varaukset. Poistojen ja varausten määrään vaikuttavat tulos ja tilan osakkaiden määrä. Perheviljelmällä tavoitteellisena ansiotulon määränä euroa/henkilö voidaan pitää valtion tuloveroasteikon alarajaa eli $16300 €$ vuonna 2014. Tästä ylimenevän tulonosuus kannattaa pyrkiä merkitsemään pääomatuloksi. (Aalto 2013.) 
Arvionvaraiset erät huomioidaan maatalouden verotuksessa tilinpäätöksen yhteydessä. Tällaisia verotuksessa vähennyskelpoisia eriä ovat muun muassa työhuonevähennys, maatalouden matkakulut, tilapäisten maatilan ulkopuolelle tapahtuvien työmatkojen elantokustannukset, opinto- ja koulutus-matkakulut, työntekijöille tarjotut luontoisedut sekä maatalouden osuudet vesi-, sähkö-, puhelin- ja atk-kustannuksista. Ne kannattaa hyödyntää täysimääräisinä, vaikka niiden verosuunnittelullinen merkitys on rajallinen. Arvionvaraisten erien arvioimiseen käytetään Verohallinnon yhtenäistämisohjeita, ellei muita selvityksiä ole. (Savolainen 2015; Verohallinto 2014.)

\section{Pitkän aikavälin verosuunnittelu, huomattava kilpailuetu}

Verosuunnittelussa hyvin oleellista on pitkän aikavälin suunnittelu. Tiedot tilan taloudellisista tunnus-luvuista, mahdollisimman tarkka kirjanpito ja laskelmat maksuvalmiudesta antavat mahdollisuuden suunnitella tulevaisuutta. Markkinahäiriöt ja siitä johtuvat tuotantohintojen laskut on sen sijaan hankala arvioida, mutta osaan niistäkin voi varautua. Lähtökohtana suunnittelussa kannattaa pitää tilan verotuksen tasaisuutta pitkällä aikavälillä. Tähän päästään suunnitelmallisilla poistoilla ja varauksilla, tuotannon ja hankintojen tasaisuudella, lainan lyhennysten hallinnalla, sekä nettovarallisuuden suunnittelulla. (Aalto 2013; Agronet 2015; Savolainen 2015.)

Verosuunnittelua toteuttaakseen tulee määrittää verotettavalle tulolle tavoitetaso. Yleensä maatilalla järkevä tulostaso on tulot vähennettynä muuttuvilla kuluilla, keskimääräisillä korvausinvestoinneilla, maatalouden lainojen koroilla ja poistopohjalla, joka on jaettu 10-15 vuodelle. Verosuunnittelun edetessä vertaillaan tarvittaessa esimerkiksi yhtiöittämisen mahdollisia verohyötyjä. (Aalto 2013; Savolainen 2015.)

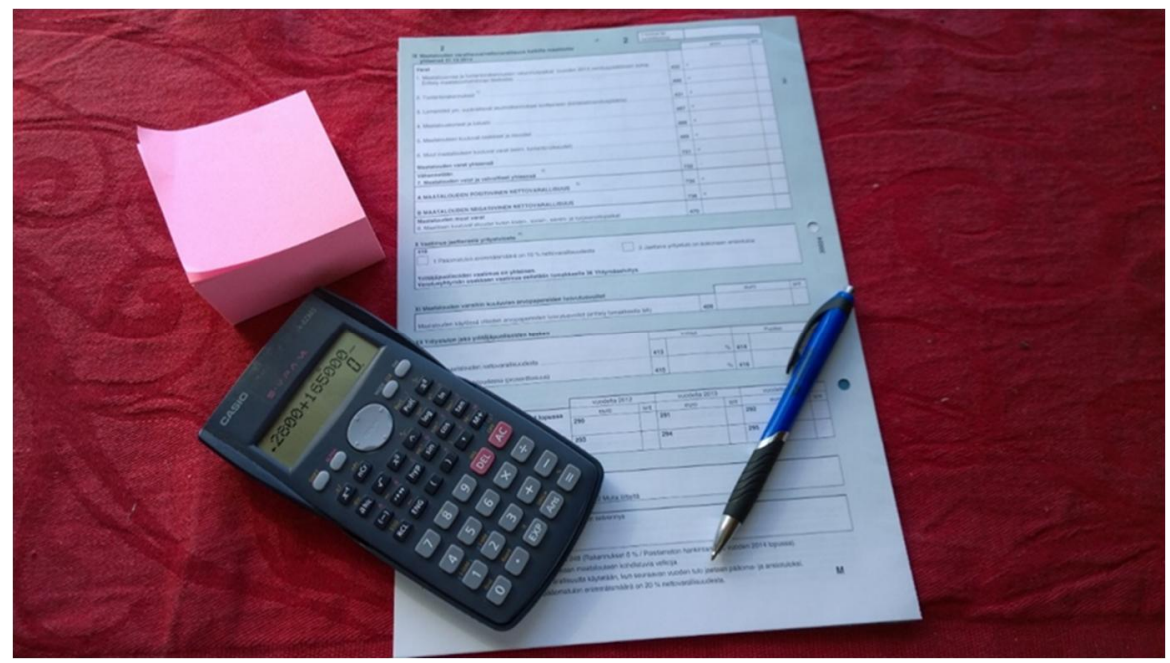

KUVA 1. Maatalouden veroilmoituksen sivulla 4 käsitellään maatilan nettovarallisuutta. (Sirviö 2015.)

Verosuunnittelun toteuttaminen tulojen ansio- ja pääomatuloihin jakamisen osalta edellyttää maatilalla positiivista nettovarallisuutta. Nettovarallisuus lasketaan vähentämällä maatalouden varoista maatalouteen kuuluvat velat (Kuva 1.). Veloista nettovarallisuutta vähentävät ainoastaan maatalouteen kuuluvat velat, ei metsäeikä yksityistalouteen kuuluvat velat. (Savolainen 2015; Verohallinto 2012.)

Maatalouden tulojen ansaitseminen ansiotuloina on verotuksen kannalta edullisempaa siihen saakka, kun ansiotulojen veroprosentti saavuttaa pääomatuloveroprosentin. Ansiotulot kannattaa pyrkiä pitämään tasaisena, progressiivisen verotuksen vuoksi, sillä tällöin myös verojen määrä pysyy tasaisena. Pääomatuloosuuden laskennassa nettovarallisuus lasketaan vähentämällä edellisen verovuoden varoista edellisen verovuoden velat sekä lisäämällä erotukseen $30 \%$ verovuonna maksetuista ennakonpidätyksen alaisista palkoista. Edellisen laskutoimituksen tuloksesta, yrittäjän valinnan mukaan, 0,10 tai $20 \%$ on pääomatulo-osuuden määrä (Kuvio 2.). Ansiotulo-osuus saadaan, kun maatalouden jaettavasta yritystulosta vähennetään pääomatuloosuus Jos yrittäjän valinta on $0 \%$ tai maatilan nettovarallisuus on nolla tai negatiivinen kaikki tulo on ansiotuloa. (Savolainen 2015; Verohallinto 2015.)

\section{Verosuunnittelu Case Peltolan tilan eri toimintavaiheissa}

Verosuunnittelun vieminen tilatasolle ja siellä oman tilan verosuunnittelumallin löytäminen on avain onnistuneeseen lopputulokseen. Tilat ovat hyvin erilaisissa lähtökohdissa, joten yhden oikean mallin luominen on 
hankalaa, tämän vuoksi jokaisen on kyettävä poimimaan omalle tilalle käyttökelpoiset keinot verotuksen suunnitteluun.

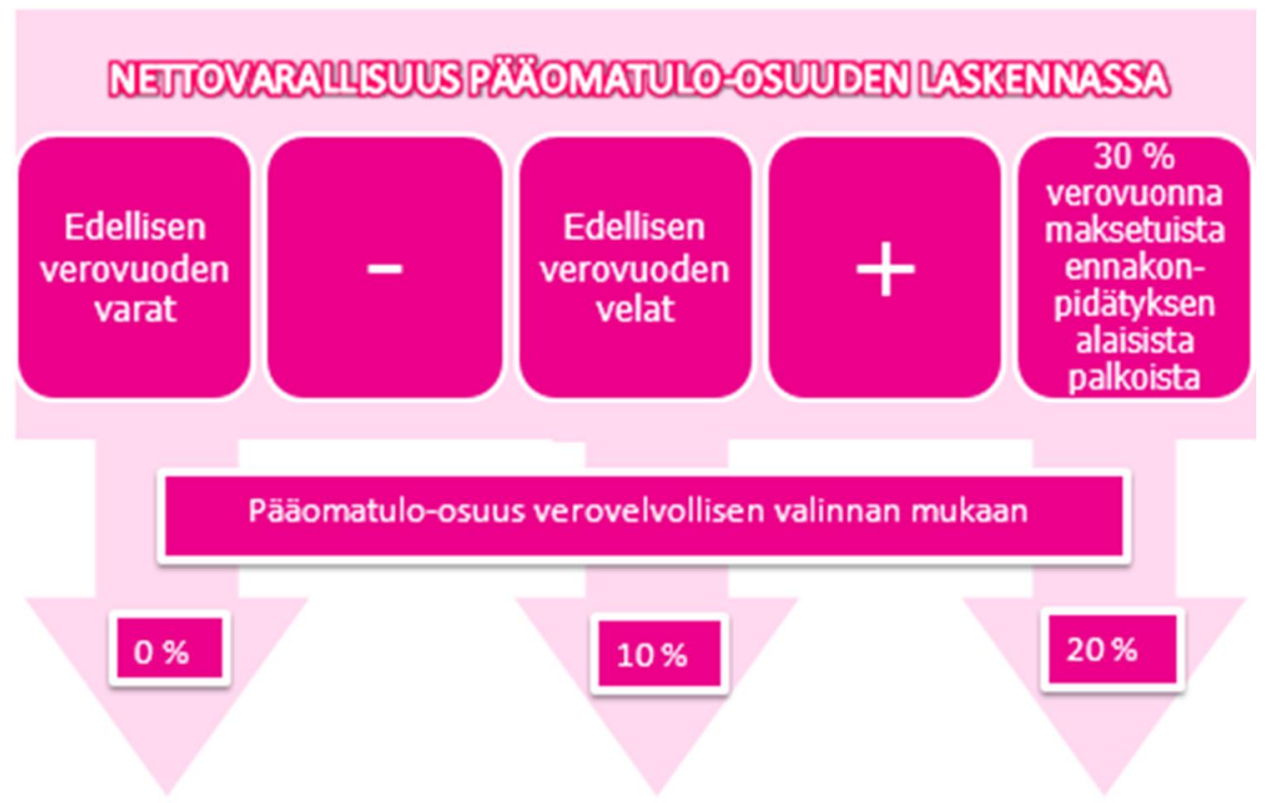

KUVIO 2. Pääomatulo-osuuden määrittäminen. (Savolainen 2015; Verohallinto 2015.)

Tutkimuksen kohteena olleella case Peltolan tilalla voitiin tehdä muutamia johtopäätöksiä tilan verosuunnitteluun liittyen. Tila kuului tuloksen perusteella keskimääräistä paremmin menestyviin. Peltolan maatilalla oli pohdittu tilan strategisia toimia monen investoinnin osalta tarkasti. Tilan tekemä tulos oli hyvällä tasolla, mistä johtuen myös verosuunnittelulle oli tarvetta. Vaiheittainen sukupolvenvaihdos antoi Peltolan tilalla lisää mahdollisuuksia verosuunnitteluun. Vaiheittaisen sukupolvenvaihdoksen taustalla oli kuitenkin muitakin syitä, kuin verosuunnittelukeinojen lisääminen. Tila kykeni laajenemaan, kun jatkaja sai vuokrattua naapurin pellot luopumistuelle jäävältä viljelijältä. Verotusyhtymän aikana tilalla luotiin strategiaa tulevista tilan kehittämistoimista. Sukupolvenvaihdokseen varauduttiin viiden vuoden aikajänteellä, mutta lopulta sukupolvenvaihdoksen toinen vaihe tulikin hieman suunniteltua aiemmin johtuen muuttuvista luopumistukisäädöksistä.

Sukupolvenvaihdoksen toisessa vaiheessa oli myös lahjaverosuunnittelun kannalta edullista, että Peltolan tilan jatkajat olivat avioliitossa tai heillä olisi ollut yhteinen lapsi. Tällä saavutettiin merkittäviä lahjaverosäästöjä, koska sukupolvenvaihdosluovutus voitiin tehdä luopujan lapselle ja hänen puolisolleen yhteislahjoituksena, jota verotettiin I-lahjaveroluokassa. Yhteislahjoitus on usein selvästi edullisempi verrattuna lapsen ja hänen puolison erillislahjoihin, koska puolison vero määräytyisi tällöin II-veroluokassa. Sukupolvenvaihdoksen toisessa vaiheessa edettiin Peltolan tilalla kauppahinnan osalta ensimmäisen vaiheen suunnitelman mukaisesti. Tila siirtyi jatkajille lahjanluontoisella kaupalla ja luopujat jäivät luopumistuelle. Suurin osa sukupolvenvaihdoksen kauppahinnasta kohdistui metsään, ja siitä johtuen jatkajille ei muodostunut kohtuuttomasti maatalouden velkaa. Jatkajien kannalta oli hyvä lähteä suunnittelemaan tilan verotusta, kun poistopohjaa oli käytettävissä ja tilan nettovarallisuus oli positiivinen. (Savolainen 2015.)

Peltolan tilalla toiminnan osakeyhtiöittäminen oli verosuunnittelunäkökulmasta tarkasteltaessa järkevää, koska tila kehittyi jatkuvasti ja tilan tulos oli hyvällä tasolla. Tilalla oli tiedossa peltokauppa, jonka jatkajat saivat hankittua lisämaakaupaksi tilalle. Perheviljelmään verrattuna Peltolan tila Oy sai maksetun kauppahinnan pellon osalta taseeseen, mikä ei rasittanut tilan nettovarallisuutta verrattuna perheviljelmänä toimimiseen. Peltolan tila Oy hyötyi yhtiöittämisen myötä myös siitä, että tilalliset tarvitsivat vain osan maatilan tuloksesta yksityistalouden menoihin. Loppuosa tuloksesta pystyttiin jättämään Peltolan tila Oy:lle esimerkiksi korvausinvestointeihin. Yhtiöittäminen pian sukupolvenvaihdoksen jälkeen oli edukasta varainsiirtoveron osalta, koska Peltolan tilalla oli korkotukilainaa sukupolvenvaihdoksesta jäljellä, mikä oikeutti varainsiirtoverovapauteen. Peltolan tila Oy ei omistanut Peltolan tilan metsiä, koska tilalla ei haluttu metsien olevan osakeyhtiön omistuksessa. Tämä olisi johtanut esimerkiksi metsävähennyspohjan käyttämättä jättämiseen. Lahjaveroa ei kannattanut välttää säästääkseen veroissa, koska sukupovenvaihdoksen verohuojennusten ansiosta kauppahinnan lahjaverotus pysyi maltillisena. (Paavilainen 2015; Savolainen 2015.) 
Peltolan tilan toiminnan osakeyhtiöittämisellä saavutettiin merkittävimmät verohyödyt vuositasolla. Edellytyksenä tälle on maltilliset, $30000 €: n$, vuotuiset yksityistalouden menot yrittäjää kohden. Taulukosta 2. voidaan nähdä, että tilan toimiessa kolmihenkisenä verotusyhtymänä, maatalousyhtymän, veroseuraamukset ovat osakeyhtiön kanssa samassa suuruusluokassa.

TAULUKKO 2. Kokonaisveroseuraamus Peltolan tilalla maatilan toimintamuodosta riippuen verovuonna 2014.

\begin{tabular}{|c|c|c|c|c|}
\hline $\begin{array}{c}\text { Peltolan tila } \\
\text { Tulos } 130000 € \\
\text { (Nettovarallisuus } \\
400000 € \text { ) }\end{array}$ & $\begin{array}{c}\text { Ansiotuloveron } \\
\text { määrä, } €\end{array}$ & $\begin{array}{c}\text { Pääomatuloveron } \\
\text { määrä, } €\end{array}$ & $\begin{array}{c}\text { Yhteisövero, } \\
€\end{array}$ & $\begin{array}{c}\text { Yhteensä, } \\
€\end{array}$ \\
\hline Yksi yrittäjä & 15800 & 24800 & - & 40600 \\
\hline Perheviljelmä (2hlö) & 10200 & 24000 & - & 34200 \\
\hline $\begin{array}{l}\text { Maatalousyhtymä } \\
\text { (3hlō) }\end{array}$ & 6300 & 24000 & - & 30300 \\
\hline $\begin{array}{l}\text { Osakeyhtiö ( } 2 \text { yrittajjää } \\
\text { palkkasuhteessa, palkka } \\
30000 € / \mathrm{hlo}, \\
\text { tulos } 70000 € \text { ) }\end{array}$ & 14000 & - & 14000 & 28000 \\
\hline
\end{tabular}

\section{Johtopäätökset}

Verosuunnittelun tärkeimpinä elementteinä ovat pitkän aikavälin suunnittelu sekä hyvä tuloksentekokyky. Ainoastaan hyvin tuottavilla maatiloilla on tarvetta ja mahdollisuuksia harjoittaa verosuunnittelua sanan varsinaisessa merkityksessä. Verosuunnittelu kannattaa jakaa pitkän aikavälin suunnittelusta vielä pienempiin osiin, joita ovat tilikauden aikana sekä tilinpäätöksen yhteydessä tehtävä verosuunnittelu. (Kuvio 3.)

Tuloksentekokyvyn laittaminen maatilalla kuntoon, on ensiarvoisen tärkeää tilan menestymisen kannalta. Nettovarallisuus on pyrittävä saamaan kaikin mahdollisin keinoin mahdollisimman hyvälle tasolle. Nettovarallisuuden ollessa korkea, voidaan suurempi osa tuloista jakaa pääomatuloksi. Tilan edellisvuoden nettovarallisuuteen lisätään $30 \%$ verovuonna maksetuista ennakonpidätyksen alaisista palkoista, jonka jälkeen tästä voidaan valita 0,10 tai $20 \%$ :n osuus pääomatuloiksi.

Suunnitelmalliset poistot ja verovelan syntymisen välttäminen ovat keskeisessä roolissa onnistunutta verosuunnittelua pohdittaessa. Poistokohteet tulee järjestää oikeaan järjestykseen, jotta nettovarallisuuden säilyttäminen hyvällä tasolla sekä maksettavan kiinteistöveron määrä olisi huomioitu tilan verosuunnittelussa. Poistojen määrää kannattaa verrata maksettavien lyhennysten määrään. Mikäli poistot ovat lyhennysten suuruiset, ollaan vielä hyvällä pohjalla verosuunnittelua ajatellen. Tasausvarausta voidaan käyttää nykyisin keskimääräistä suuremmalla tilalla vain nettovarallisuuden väliaikaisena parantajana. Sen hyödyntäminen esimerkiksi salaojitusinvestointiin on toimiva keino, mutta muuten tasausvarauksen merkitys on pienenemään päin tilakoon kasvaessa.

Rahoitus kannattaa pohtia tilatasolla verotusta silmällä pitäen. Oikeaoppinen jako maa-, metsä- ja yksityistalouden velkaan otettaessa uutta luottoa, on ensisijaisen tärkeää, jottei maatilan nettovarallisuutta heikennettäisi turhaan. Eläinrahoitus ja leasing-rahoitus voivat olla tietyntyyppiselle tilalle varteenotettavia rahoitusmuotoja, jolloin voidaan saavuttaa merkittäviä verosuunnittelullista hyötyjä.

Osuustoimintaan pohjautuva maidon- ja lihantuotanto on usein hyvä nettovarallisuuden parantamiskeino tilatasolla. Vakavarainen osuuskunta mahdollistaa, että maksettu osuusmaksu kasvattaa huomattavasti tilan nettovarallisuutta. Tämän lisäksi sijoitetulle osuuspääomalle saa verotuksellisesti edullista osuuspääoman korkoa.

Lähtökohtaisesti yhden henkilön maatalousverotus on aina melko raskasta, mikäli tila tekee hyvää tulosta. Yhteinen lapsi tai avioliitto mahdollistaa perheviljelmänä toimimisen, jolloin tulosta voidaan jakaa puolisolle. 15-17-vuotiaille lapsille kannattaa myös aina maksaa palkkaa tehdystä työstä. Alle 18-vuotiaan perheenjäsenen palkkaamisen kuluvat sivukulut sekä veroseuraamukset ovat aivan minimaaliset ja samalla lapsen vanhempi voi saavuttaa merkittävää verosäästöä. Vaiheittainen sukupolvenvaihdos sopii 
verosuunnittelua ajatellen maatilalle, joka tekee melko hyvää tulosta. Usein vaiheittaisen sukupolvenvaihdoksen syyt voivat olla osittain tai kokonaan muut kuin verosuunnittelulliset.

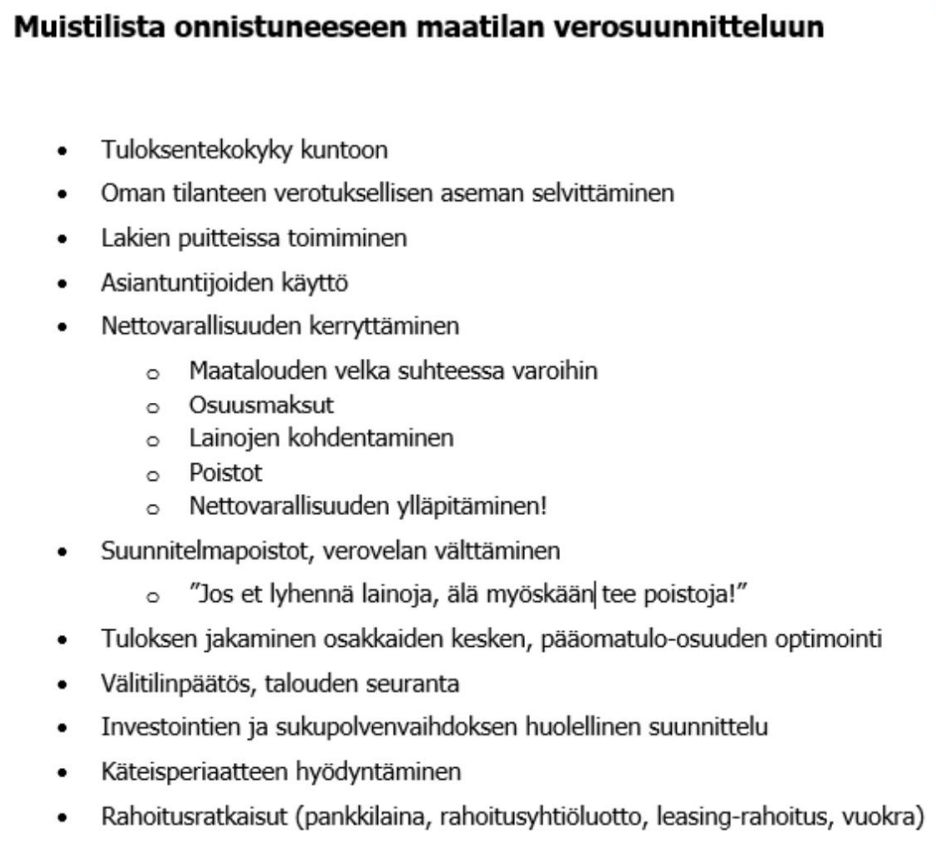

KUVIO 3. Maatilan verosuunnittelun muistilista.

Jaettaessa maatilan tulosta useammalle, pienenee kokonaisveroaste, koska ansiotulo on progressiivisesti verotettua ja myös pääomatuloverossa on lievä progressio.Samalla tilan nuori jatkaja saadaan omistajaksi tilaan, mikä on palkkasuhdetta järkevämpää. Vaiheittainen suku-polvenvaihdos mahdollistaa jatkajan vuokraamaan tai ostamaan lisämaata ja näin kehittämään tilan toimintaa.

Onnistuneessa sukupolvenvaihdoksessa keskeisintä on hyvä suunnittelu ja ennakkoratkaisut, jotta yllätyksiltä vältytään. Kauppahinta kannattaa määrittää lopullisen tilakaupan osalta jo ensimmäisessä vaiheessa, samoin suunniteltava aikataulu. Lahjaveroa ei kannata välttää säästääkseen veroissa, koska sukupovenvaihdoksen verohuojennusten ansiosta kauppahinnan maksu on jatkajan kannalta aina huomattavasti raskaampaa. Verosuunnittelun kannalta lahjaveroissa on oleellista, ovatko jatkajapariskunta naimisissa tai onko heillä yhteinen lapsi. Avopuolisolle tehtyä luovutusta verotetaan aina II-lahjaveroluokassa, jolloin lahjavero on huomattavasti suurempi verrattuna lahjaveroon mikä määräytyy aviopuolisoiden yhteislahjalle

Usein sukupolvenvaihdoksen jälkeen maatilaa kehitetään tilasta riippuen hieman erilaisilla strategioilla. Oleellista on se, että investointeihin valmistaudutaan useamman vuoden ajan. Investoinnin tarkoituksena on aina lisätä tilan tuloksentekokykyä tai vähentää työmäärää. Tuloksentekokyvyn nostaminen uudelle tasolle kannattaa huomioida investointia suunniteltaessa. Verojenmaksu tulee investoinnin myötä vain kasvamaan. Kiinteistövero on monelle hyvin yllätyksellinen menoerä esimerkiksi navettainvestoinnin jälkeen. Muutamien satasien vuotuinen kiinteistövero voi nousta esimerkiksi 12500 euroon miljoonanavetassa.

Joskus tilaa kehitettäessä voi olla riskienhallinnan sekä verosuunnittelun kannalta järkevää yhtiöittää maatilan toiminta osakeyhtiömuotoiseksi. Lähtökohtana kuitenkin on, että kaikki muut keinot kannattaa hyö- 
dyntää ennen yhtiöittämistä ja yhtiöittäminen on kyettävä perustelemaan monesta eri näkökulmasta. Yhtiöittämisen myötä osakeyhtiö toimii MVL:n alaisena, mikäli osakeyhtiö omistaa peltoa. Yhtiöittäminen vaatii paljon aikaa ja siitä koituu kustannuksia. Keskeinen verosäästö saavutetaan, mikäli tilalla on sukupolvenvaihdoksesta korkotukilainaa jäljellä. Tämä mahdollistaa yhtiöittämisen varainsiirtoverovapaasti. Yhtiöittämisen myötä esimerkiksi pellon hankintakustannuksen suuruiset arvot saadaan taseeseen, mikä kasvattaa tilan nettovarallisuutta. Pienet yksityistaloudenmenot mahdollistavat sen, että osa yhtiön tuloksesta jätetään yhtiöön esimerkiksi korvausinvestointeja varten. Tällä tehdään huomattavia verosäästöjä.

Tehtäessä yhtiöittäminen toimintamuodon muutoksena ja siirrot apporttisiirtoina, ei toiminnasta aiheudu tulovero- eikä arvonlisäveroseuraamuksia. Yhtiöittämisen lähtökohtana on pitkän aikavälin koko ajan positiivisesti kehittyvä tulos. Yhtiöittämisen on katettava siitä aiheutuneet kustannukset neljässä vuodessa syntyneillä verosäästöillä, jotta sitä voidaan pitää perusteltuna. Metsää ei kannata laittaa yhtiön haltuun, ellei se ole rahoittajan näkökulmasta elinehto. Yhtiö ei kykene hyödyntämään metsävähennyspohjaa ollenkaan. Yhtiöitettäessä maatila tulee vielä muistaa, että osakeyhtiö ei tee yhtään tehtävistä töistä, vaan työt päinvastoin lisääntyvät lisääntyneen kirjanpitotyön myötä. Tarvitaan asennemuutos eli perheviljelmän epätarkasta yritystilin käytöstä siirrytään osakeyhtiön rahaliikenteen tarkkaan toteutukseen ja seurantaan.

\section{Kirjallisuus}

Aalto, E. 2013. Maatilan verotus. [Verkkodokumentti]. ProAgria Länsi-Suomi. [Viitattu 19.3.2015]. Saatavissa: http://lansisuomi.proagria.fi/sites/default/files/attachment/maatilanverotusverovuosi2013.pdf

Agronet. 2015. Tilan johtaminen. Eläkemaksut. [Viitattu 5.1.2015]. Saatavissa: https://portal.mtt.fi/portal/page/portal/agronet/Tilanjohtaminen/Verosuunnittelu/elakemaksut

Agronet. 2015. Tilan johtaminen. Investoinnit ja poistot. [Viitattu 3.1.2015]. Saatavissa: https://portal.mtt.fi/portal/page/portal/agronet/Tilanjohtaminen/Verosuunnittelu/investoinnit

Agronet. 2015. Tilan johtaminen. Pääoma- ja ansiotulot. [Viitattu 5.1.2015]. Saatavissa: https://portal.mtt.fi/portal/page/portal/agronet/Tilanjohtaminen/Verosuunnittelu/Paaoma_ansiotulot

Agronet. 2015. Tilan johtaminen. Tasausvaraus. [Viitattu 3.1.2015]. Saatavissa: https://portal.mtt.fi/portal/page/portal/agronet/Tilanjohtaminen/Verosuunnittelu/Tasausvaraus

Agronet. 2015. Tilan johtaminen. Verosuunnittelu. [Viitattu 3.1.2015]. Saatavissa: https://portal.mtt.fi/portal/page/portal/agronet/Tilanjohtaminen/Verosuunnittelu

Finlex. 2014. Laki elinkeinotulon verottamisesta. [Viitattu 3.12.2014]. Saatavissa: http://www.finlex.fi/fi/laki/ajantasa/1968/19680360

Finlex. 2014. Maatilatalouden tuloverolaki. [Viitattu 3.12.2014]. Saatavissa: http://www.finlex.fi/fi/laki/ajantasa/1967/19670543

Finlex. 2014. Tuloverolaki. [Viitattu 3.12.2014]. Saatavissa: http://www.finlex.fi/fi/laki/ajantasa/1992/19921535

Kiviranta, E. 2013. Poistetaanko verotuksen tulolähdejako? Käytännön maamies, 1/2013, 39.

Koivumäki, J. Lakiasiat. Tulolähteiden merkitys verotuksessa. [Viitattu 18.2.2015]. Saatavissa: http://jasentiedote.chamber.fi/index.php/jasentiedote/Lakiasiat/Tulolaehteiden-merkitys-verotuksessa

Ojala, I. Tuloverotuksen tulolähteet. Verokoulu osa 1/12. [Viitattu 18.2.2015]. Saatavissa: http://tilisanomat.fi/content/tuloverotuksen-tulol\%C3\%A4hteet

Paavilanen, Juhani 2015. Yritysasiantuntija. Iisalmi 9.3.2015. Haastattelu.

Savolainen, Risto 2015. Verotuksen ja taloushallinnon huippuosaaja. Juankoski 30.1.2015. Haastattelu.

Savolainen, R. 2015. Verosuunnittelu maataloudessa. Käytännön maamies 1/2015, $42-44$

Verohallinto. 2015. Maatalouden tulot ja menot. [Viitattu 5.4.2015]. Saatavissa: https://www.tax.fi/fi-FI/Yritys_ja_yhteisoasiakkaat/Maatalousyrittaja_ja_metsanomistaja/Tuloverotus/Maatalouden_tulot_ja_menot

Verohallinto. 2014. Verohallinnon yhtenäistämisohjeet. Vuodelta 2014 toimitettavaa verotusta varten. Dnro $191 / 200 / 2014$

Verohallinto. 2012. Syventävät vero-ohjeet. Maatalouden nettovarallisuus ja sen arvo. [Viitattu 12.2.2015]. Saatavissa: http://www.vero.fi/fi-FI/Syventavat_veroohjeet/Varojen_arvostaminen/Maatalouden_nettovaralli-

suus_ja_sen_arvo\%2825846\%29

Verohallinto. 2012. Syventävät vero-ohjeet. Verohallinnon päätös pellon keskimääräisestä vuotuisesta tuotosta ja salaojistuslisästä. [Viitattu 12.2.2015]. Saatavissa: http://www.vero.fi/fi-FI/Syventavat_veroohjeet/Verohallinnon_paatokset/Verohallinnon_paatos_pellon_keskimaarais\%2824827\%29

Verohallinto 2011. Sanasto. Tulolähde. [Viitattu 23.2.2015]. Saatavissa: http://www.vero.fi/fi-FI/Syventavat_veroohjeet/Sanasto/Tulolahde\%2813782\%29 